\title{
THE FUTURE OF INSIDER TRADING IN AUSTRALIA: WHAT DID RENE RIVKIN TEACH US?
}

\author{
JULIETTE OVERLAND*
}

[The case of $R v$. Rivkin ${ }^{1}$ is one of the very few Australian cases resulting in a conviction for insider trading, making it a landmark case in this area of the law. This article examines developments in Australian law relating to insider trading in light of this decision of the New South Wales Court of Criminal Appeal. Aspects of the insider trading offence which have been clarified by Rivkin's case are examined and discussed, as are those which remain contentious or unclear despite the judgment. The essential elements of the insider trading offence are reviewed in this context, particularly in light of recent legislative reform and relevant academic commentary. This article also considers the role of the courts in interpreting difficult legislative provisions such as the laws regulating insider trading, as well as providing an international perspective by analysing the potential application of key provisions of the legislative regimes of other jurisdictions. Clarification of contentious aspects of insider trading has been much needed, so despite the continuing absence of clarity in relation to some elements of the offence, judicial pronouncement by a higher court on these issues should be viewed as a welcome development to the laws on insider trading.]

\footnotetext{
* Associate Lecturer, Division of Law, Department of Business Law, Macquarie University. Many thanks to Professor Stephen Bottomley of ANU and Alex Steel of UNSW for the helpful comments they provided on an earlier version of this article.

${ }^{1}$ R v. Rivkin, [2004], 60198/03, (Unreported, Mason P, Wood CJ and Sully J, Feb.5, 2004) (NSWCCA, 2004) (“Rivkin's Case”).
} 


\section{INTRODUCTION}

Insider trading regulation has long been viewed as an extremely difficult and complicated area of corporate law. Australian insider trading laws have been considered by judges and academics alike to be overly complex, legalistic and unclear, ${ }^{2}$ as well as being "couched in language which is difficult of understanding and application."” Whilst the analysis of insider trading laws has been a popular topic amongst academic writers in recent times - in particular, on issues such as whether insider trading should be decriminalized, and how to address the perceived difficulties in successfully prosecuting and convicting insider traders ${ }^{4}$ - there have been very few prosecutions of insider trading in Australia and, as a result, there are very few decided cases on this area of the law. Indeed, the comment has been made that "there are many more journal articles discussing what [insider trading] should be than reported cases of what it is." 5

In this context, the prosecution and conviction of Mr Rene Rivkin for insider trading should be viewed as a landmark case in Australia for several reasons: it is one of the extremely few successful prosecutions of insider trading in Australia, especially one following a plea of "not guilty"; the appeal against the conviction at trial provided a rare opportunity for a higher court to analyse the various elements of the insider trading offence; and several of the legal arguments raised at trial and on appeal were novel and a consideration of those issues affords a greater understanding of the insider trading offence itself.

\footnotetext{
${ }^{2}$ Michael Whincop, Towards a Proprietary Rights and Market Microstructural Theory of Insider Trading Regulation - The Case of Primary Securities Markets Transactions, 7 JouRNAL B.F.L.P. 212 (1996); Roman Tomasic, Corporate Crime: Making the Law More Credible, 8 CoMPANY S. L. J. 369, 380 (1990); CORPORATIONS AND MARKETS ADVISORY COMMITTEE, INSIDER TRADING DISCUSSION PAPER para 0.5 (2001), available at

<http://www.camac.gov.au/camac/camac.nsf/byHeadline/PDFDiscussion+Papers/\$file/Insider_Trading_ DP_June_2001.pdf> (last visited June 1, 2005).

${ }^{3}$ Ampolex Ltd v. Perpetual Trustee Trading Co (Canberra) Ltd, (1996) 20 ACSR 649, 658 per Rolfe J (NSW Supreme Court, 1996).

${ }^{4}$ See for example, Lori Semaan, Mark Freeman \& Mark Adams, Is Insider Trading A Necessary Evil for Efficient Markets?: An International Comparative Analysis, 17 ComPANY S. L. J. 220 (1999); Ashley Black, The Reform of Insider Trading Law in Australia, 15 UnIVERSITY N.S.W. L.J. 214 (1992); Vivien Goldwassser, The Enforcement Dilemma in Australian Securities Regulation, 27 AUSTRALIAN B.L.R. 482 (1999); Roman Tomasic \& Brendan Pentony, The Prosecution of Insider Trading: Obstacles to Enforcement, 22 Australian N.Z.J.C. 65 (1989). Debate on the difficulties of obtaining a successful conviction for insider trading has been reignited very recently as a result of the Australian Securities and Investment Commission's decision to pursue civil penalty proceedings against Stephen Vizard for a breach of directors' duties in respect of conduct which appears to amount to insider trading: AUSTRALIAN SECURITIES AND INVESTMENTS COMMISSION, ASIC COMMENCES CIVIL PROCEEDINGS AGAinst STEPHEN ViZARD, MEDIA AND INFORMATION RELEASE 05-190. July 4, 2005, available at <http://www.asic.gov.au/asic/ASIC_PUB.NSF/byid/E8BC0E28A45B6EA8CA257034000E6BAF?open document> (last visited July 28, 2005).

${ }^{5}$ Michael Gething, Insider Trading Enforcement: Where Are We Now and Where Do We Go From Here?, 16 COMPANY S.L.J. 607 (1998). This comment was cited and endorsed in R v. Firns, (2001) 38 ACSR 223, 234 per Mason J (NSWCCA, 2001).
} 
As there are so few judicial pronouncements on this important but complex area of corporate law, the judgment in $R v$. Rivkin ${ }^{6}$ ('Rivkin's case') is therefore invaluable to scholars of company and securities law. The judgment of the New South Wales Court of Criminal Appeal examines several aspects of the insider trading offence, the most important and consequential of which are:

(a) whether the source of information can form part of the information itself;

(b) whether information must be received under an obligation of confidence;

(c) whether the tests to determine what an alleged insider trader knew or ought to have known are subjective or objective in nature; and

(d) whether the source of information is relevant to its level of materiality.

Each of these issues will be examined in this article and analysed in the context of a review of the essential elements of the insider trading offence, pronouncements from previous cases on insider trading, recent developments and proposals relating to the elements of the insider trading offence and opinions proffered by various academic commentators. The extent to which Rivkin's case has clarified certain elements of the law of insider trading, and its likely effect on the future prosecution of insider trading offences, will also be discussed. Aspects of the insider trading offence which remain unclear and have not been resolved by the judgment in Rivkin's case will also be highlighted in this article. A brief analysis from an international perspective will follow, as well as a discussion of the role of the courts in resolving uncertainties in the elements of the insider trading offence. Although Rivkin's case also addresses other legal issues - such as periodic detention, fitness to stand trial and sentencing - consideration of those issues is beyond the scope of this article, which will focus solely on insider trading law.

\section{BACKGROUND TO RIVKIN'S CASE}

Rivkin's case received much media attention and publicity at the time of the trial and subsequent appeal, and the general nature of the facts of this case are widely known. Mr Rivkin wished to sell a house in the eastern suburbs of Sydney and instructed a real estate agent, Mr Doff, to act on his behalf. Mr Gerard McGowan, the executive chairperson of Impulse Airlines, was interested in purchasing the house and approached Mr Doff and the group operations manager of the Rivkin group of companies, Mr Dassakis.

On 24 April 2001, Mr Doff and Mr Dassakis arranged a telephone call with $\mathrm{Mr}$ Rivkin. Mr McGowan informed Mr Rivkin by telephone that he was interested in

${ }^{6}$ R v. Rivkin, [2004] 60198/03, (NSWCCA, 2004). 
buying the house, but that he wished to make a conditional offer because he was currently trying to sell his business. When pressed for further details, he informed Mr Rivkin (as well as Mr Doff and Mr Dassakis) that he was trying to "merge” Impulse Airlines with Qantas and was awaiting approval from the Australian Competition and Consumer Commission ('ACCC') for that deal. Mr Rivkin told Mr McGowan that he did not believe that the ACCC would approve such a transaction, but Mr McGowan informed Mr Rivkin that he believed ACCC approval would be forthcoming. Mr McGowan told Mr Rivkin that he could not now trade in Qantas shares, because of the knowledge Mr Rivkin now possessed about the proposed deal between Impulse Airlines and Qantas. Mr Rivkin agreed to give $\mathrm{Mr}$ McGowan a seven-day conditional contract to buy the property, which ultimately did not proceed. ${ }^{7}$

Within a matter of hours of the telephone conversation, Mr Rivkin gave instructions to a SEATS operator with Rivkin Discount Stockbroking to purchase 50,000 Qantas shares in the name of Rivkin Investments. Mr Rivkin was the sole director of Rivkin Investments and had a shareholding interest of 11\%. On 1 May 2001, on Mr Rivkin's instructions, the Qantas shares were sold for a profit of \$2,664.94. Later that same day, Qantas shares were subject to a temporary trading halt, and Impulse Airlines and Qantas then made a joint announcement that they had entered into a "virtual or contractual merger" (although the actual transaction entered into was not a true merger of the two companies). Following the joint announcement there was a significant rise in the Qantas share price. As Rivkin Investments had already sold its Qantas shares prior to the joint announcement, it did not receive the benefit of that rise in the Qantas share price, although there had been a price rise during the period in which Rivkin Investments had bought and sold Qantas shares.

Mr Rivkin was charged and prosecuted for insider trading in relation to the purchase and sale of the Qantas shares by Rivkin Investments. ${ }^{8}$ Following a jury trial and conviction for insider trading in the New South Wales Supreme Court on 30 April 2003, Mr Rivkin was fined \$30,000 and sentenced to 9 months' periodic detention by Whealy J, on 29 May 2003. ${ }^{9}$ The maximum penalty which could have been imposed was a fine of $\$ 200,000$ or imprisonment for up to 5 years or both. ${ }^{10}$ Mr Rivkin appealed against the conviction and sentence to the New South Wales Court of Criminal Appeal, which delivered its judgment on 5 February 2004. The conviction and sentence were both upheld.

\footnotetext{
${ }^{7}$ It should be noted that whilst this is the version of the facts which appears to have been accepted at trial, it was disputed by Mr Rivkin.

${ }^{8}$ Incidentally, insider trading proceedings were also brought against Mr Rivkin's real estate agent, $\mathrm{Mr}$ Doff, in relation to a purchase of 20,000 Qantas shares by a company Mr Doff controlled on 24 April 2001. Mr Doff was convicted of insider trading in the Supreme Court of New South Wales on 19 November 2004 and on 11 February 2005 was sentenced to 350 hours of community service and ordered to pay a pecuniary penalty of $\$ 37,255.25$ : Australian Securities and Investments Commission, Bart Doff sentenced for insider trading, Media and Information Release 05-23, Feb. 11, 2005, available at $<$ http://www.asic.gov.au/asic/asic_pub.nsf/byheadline/05-

23+Bart+Doff+sentenced+for+insider+trading?openDocument> (last visited June 1, 2005).

${ }^{9}$ R v. Rivkin, [2003] 70065/02, (NSW Supreme Court, 2003).

${ }^{10}$ Corporations Act, 2001, s 1311 and Schedule 3 (Cth).
} 
Mr Rivkin was tried under s1002G(2) of the Corporations Act, 2001 (Cth) ('Corporations Act') which has now been replaced by the various provisions of Division 3 of Part 7.10.11 The amendments contained in these new provisions resulted from the reforms instituted by the Financial Services Reform Act, 2001 (Cth).

\section{Relevant Legal Issues}

The primary legal issues concerning insider trading which arose for consideration in Rivkin's case were:

(a) Information: Did Mr Rivkin actually possess “information”? What is the nature and scope of the information which must be possessed? Can it include the source of the information itself? Must the information be received under an obligation of confidence?

(b) General Availability: Was the information possessed by $\mathrm{Mr}$ Rivkin “generally available”?

(c) Material Effect on the Value of Securities: Would a reasonable person have expected the information possessed by Mr Rivkin to have a material effect on the value of Qantas shares (the relevant securities)? Is the source of information relevant when considering its materiality?

(d) Knowledge: Should Mr Rivkin have known that the information was not generally available and that a reasonable person would have expected it to have a material effect on the value of Qantas shares? How subjective are the tests for determining what an alleged insider trader knew or ought to have known?

These issues will be considered in some detail in conjunction with a review of the essential elements of the insider trading offence.

\footnotetext{
${ }^{11}$ Any significant differences between the current state of the law and the state of the law at the time of Mr Rivkin's trial will be indicated in this article.
} 


\section{ELements of the InSIDER Trading OfFence}

Briefly, insider trading occurs when a person trades in shares or other financial products $^{12}$ whilst in possession of price-sensitive information which is not publicly available. The elements of the insider trading offence can be summarised as follows:

1. a person possesses certain information;

2. the information is not generally available;

3. a reasonable person would expect the information to be material (that is, to have a material effect on the price or value of certain securities);

4. the person knows (or should know) that the information is not generally available;

5. the person knows (or should know) that a reasonable person would expect the information to be material; and

6. whilst in possession of the information, the person trades in those securities (that is, buys or sells those securities) or procures another person to trade in those securities.

A brief overview and analysis of the law relating to each of these elements of the insider trading offence will follow. The impact of the decision in Rivkin's case on issues relating to each of these elements will also be examined.

\section{A person possesses certain information}

The first element of the insider trading offence requires that a person possess certain information. ${ }^{13}$

"Information" is defined to include:

(a) matters of supposition and other matters that are insufficiently definite to warrant being made known to the public; and

(b) matters relating to the intentions or likely intentions of a person. ${ }^{14}$

This broad, inclusive definition in the Corporations Act differs significantly from that contained in the legislation preceding both the Corporations Act and the Corporations Law, which required the alleged insider trader to possess "specific inform-

\footnotetext{
12 To be referred to in this article as "securities".

${ }^{13}$ Corporations Act, 2001, s 1043A (1) (a) (Cth), previously s 1002G(1).

${ }^{14}$ Corporations Act, 2001, s 1042A (Cth), previously s 1002A(1).
} 
ation". ${ }^{15}$ In recent times, Australian cases have confirmed that the current definition of "information" does not import any requirement of specificity. ${ }^{16}$

Additionally, unlike some overseas jurisdictions, ${ }^{17}$ Australian law does not contain any requirement that the alleged insider trader "use" the relevant information. It is enough that the alleged insider trader merely "possessed" the information when they traded (or procured another to trade) in the relevant securities. It is no defence to a charge of insider trading that the alleged insider trader did not rely on the inside information because, for example, they had already planned to trade prior to coming into possession of that information, or that they based their decision to trade on alternative information which was not inside information. Although the "non-use" argument was not advanced directly by counsel for Mr Rivkin in Rivkin's case, evidence was led during the trial and on appeal which presumably could be used to support a defence of non-use, if it were available - evidence was led that Mr Rivkin did not believe the information he received from Mr McGowan, and that Mr Rivkin formed his intention to purchase Qantas shares based on discussions with the SEATS operator, and not on the basis on the information he received from $\mathrm{Mr}$ McGowan. ${ }^{18}$

\section{Can the source of information form part of the information itself?}

In Rivkin's case, counsel for Mr Rivkin argued unsuccessfully that there had been an error of law at trial because the information the Crown alleged that Mr Rivkin possessed was not "information" for the purposes of the Corporations Act. Primarily, this argument was made on the basis that the relevant information possessed by Mr Rivkin was not the actual state of affairs communicated by Mr McGowan to Mr Rivkin, but instead the fact that Mr McGowan had stated that such a state of affairs existed. ${ }^{19}$ That is, Mr Rivkin knew only that Mr McGowan had stated that there was a proposed "merger" deal between Impulse Airlines and Qantas, rather than

\footnotetext{
${ }^{15}$ For example, the Securities Industry Act, 1970, s 75A (NSW), as applied in Ryan v. Triguboff, [1976] 1 NSWLR 588 (NSW Supreme Court, 1976). This is also the position in several overseas jurisdictions, such as the United Kingdom and Canada: Criminal Justice Act, 1993, s 56 (1) (b) (UK); Business Corporations Act, RSC 1985, c C-44, s 131 (Canada). In its recent report on insider trading, the Corporations and Markets Advisory Committee concluded that it would not be appropriate to amend the law to impose a requirement that information be "specific": CORPORATIONS AND MARKETS ADVISORY COMMITTEE, INSIDER TRADING REPORT, para 3.7 (2003), available at

<http://www.camac.gov.au/camac/camac.nsf/byHeadline/PDFFinal+Reports+2003/\$file/Insider_Trading _Report_Nov03.pdf> (last visited June 1, 2005).

${ }^{16}$ See for example, Ampolex Ltd v. Perpetual Trustee Trading Co (Canberra) Ltd, (1996) 20 ACSR 649, 658 per Rolfe J (NSW Supreme Court, 1996); R v. Hannes, [2000] NSW CCA 503, para 28 per Spigelman CJ (NSWCCA, 2000).

17 Germany, for example, requires evidence of "use" of inside information: Securities Trading Act, 1994, s 14 (1) (Germany). Countries such as the United Kingdom and South Africa provide a defence of "non-use" of inside information to charges of insider trading: Criminal Justice Act, 1993, s 53 (UK); Insider Trading Act, 1998, s 4 (South Africa).

${ }^{18}$ The issues of "specificity" and "non-use" of information will be readdressed in an international context at paragraph VI below.

${ }^{19}$ Rivkin's case, para 123 to 124.
} 
that such a proposal actually existed. It was argued that Mr Rivkin could only have been in possession of "information" if he had actually known for certain that a proposal for a "merger” deal definitely existed, which he did not. ${ }^{20}$

The Court rejected this argument easily. Whilst the source of information may obviously impact on its perceived reliability, and this will be discussed further below, ${ }^{21}$ it is clear that the source or origin of information can also be considered to form part of that information as well. This was clearly recognized by the Court in Rivkin's case, as it concluded that "information included the source and state of affairs communicated” (emphasis added). ${ }^{22}$

It is not surprising that the Court reached this conclusion and rejected the proposition that an alleged insider trader would possess "information" only if they had knowledge that a certain state of affairs existed, rather than mere knowledge that someone had said that a certain state of affairs existed. A person should not need to have knowledge or a belief in the truth of information they possess before they are caught by the prohibition on insider trading. It should be enough that the person merely possesses the information. If knowledge as to the truth of information was required, rumours and gossip would almost never amount to "information". Insiders trading on the basis of a rumour would merely need to argue that they did not necessarily know whether or not the rumour was true, only that they had heard and acted upon it, in order to escape liability. Share trading based upon rumour and speculation could therefore occur almost with impunity, as it would be almost impossible to prove that a person knew information they possessed to be true. This would then add yet another layer of complexity to the already convoluted questions about what an alleged insider trader knew or ought to have know, which will be discussed below. ${ }^{23}$ Elaborate tests would need to be developed for the purpose of trying to determine whether or not a defendant had any knowledge as to the truth of information they had received. The imposition of such further tests would not assist in simplifying this already complex area of corporate law.

Clearly, as the definition of "information" includes matters of supposition, and there is no requirement that "information" be specific or precise, ${ }^{24}$ a defendant should not be required to have actual knowledge as to the truth of a rumour or any other form of information in order to be caught by the insider trading prohibition.

\footnotetext{
${ }^{20}$ Interestingly, mergers and takeovers are often considered to provide a unique opportunity for potential insider traders. This was recognised by the Corporations and Markets Advisory Committee, supra note 2, para 1.1. This issue has also been the subject of detailed academic review: TOM ARNOLD, GAYLE ERWin, LANCE NAIL \& TERRY NiXON, What Is THE FORM OF INFORMED TRADing In Options MARKETS PRECEDING TENDER OFFER ANNOUNCEMENTS (2004), available at

<http://www.fma.org/Chicago/Papers/InformedOptions.pdf\#search> (last visited June 1, 2005); PHILIP BROWN \& MARK FoO, INSIDER TRADING IN AUSTRALIA: EVIDENCE FROM DiRECTORS' TradEs, UNIVERSITY OF WESTERN AUSTRALIA WORKING PAPER (1998), available at

<http://www.af.ecel.uwa.edu.au/accfin/research/working_papers/1998> (last visited June 1, 2005).

${ }^{21}$ To be discussed in more detail at paragraph IV $\mathrm{C} 1$ below.

${ }^{22}$ Rivkin's case, para 132.

${ }^{23}$ See below.

${ }^{24}$ See above.
} 
Additionally, there has been judicial recognition that "information" could include "a rumour that something has happened... which a person neither believes nor disbelieves." 25 Presumably therefore, "information” could also include a rumour that something may be about to happen, which a person neither believes nor disbelieves.

Issues of reliability and materiality aside, when one considers the types of information which circulate in the financial marketplace, there is obviously a distinction to be made between the following examples of information:

(i) A press release addressed to the ASX and signed by the company secretary of ABC Ltd which states that ABC Ltd is about to launch a takeover bid for XYZ Ltd.

(ii) A statement from a trusted stockbroker that he has heard that ABC Ltd is about to launch a take-over bid for XYZ Ltd.

(iii) A statement overheard whilst walking in the street that a passer-by's brother has heard that ABC Ltd is about to launch a take-over bid for XYZ Ltd.

If one imagines hearing about each of these pieces of information from a third party, it becomes clear that the source of each piece of information forms a vital part of the information itself. If the source were disregarded as a potential element of the information itself, each piece of information above would be identical - that is, that ABC Ltd is about to launch a take-over bid for XYZ Ltd. Including the source as part of the information itself substantially changes the nature of each of these three pieces of information.

Obviously rumours which circulate in the financial market place can have an impact on the price or value of securities, whether or not those rumours are actually based in fact. The financial services industry clearly operates, at least occasionally, on the basis of speculation and rumour, as well as on more substantiated sources of information. This must be reflected in market trading offences, such as insider trading. The Court is to be commended for clarifying this issue and making it clear that the source of inside information can form part of the information itself.

\footnotetext{
${ }^{25}$ Hooker Investments Pty Ltd v. Baring Bros Halkerston \& Partners Securities Ltd, (1986) 10 ACLR 462, 468 per Young J (NSW Supreme Court, 1986).
} 

obligation of confidence?

In Rivkin's case, counsel for Mr Rivkin contended that, in order to fall within the prohibition on insider trading, any information possessed by an alleged insider trader must have been received under an obligation of confidence. This argument was rejected by the Court, on the basis that there is no reason to suggest that the legislation requires such a condition to be imposed. ${ }^{26}$

It would actually have led to a curious result if the Court had accepted an argument that no offence of insider trading is committed unless the relevant "information" was received under an obligation of confidence. It would generally be assumed that this would only occur in limited circumstances, such as where the source of the information is a person connected with the relevant company who does not wish the information to become widely known.

The imposition of a requirement that information be received under an obligation of confidence would have a similar effect to the imposition of a requirement that a person must have knowledge as to the truth of information received - it would virtually exempt persons trading on the basis of rumour and gossip from the prohibition on insider trading. Whilst adding an additional factual analysis to the question of whether insider trading has occurred - by requiring the tribunal of fact to be satisfied that information was received confidentially - the imposition of such a requirement would not reduce any of the complexity or difficulty associated with the insider trading offence. It would merely permit those who can demonstrate that they did not receive information confidentially or, perhaps more importantly, those against whom it cannot be proved that such confidentially existed, to trade freely on the basis of such information. The most likely beneficiaries of such an additional requirement would be those who trade on rumour and gossip. Once again, the imposition of any further tests would not assist in simplifying this already complex area of corporate law.

\section{The information is not generally available}

The second element of the insider trading offence requires that the information possessed by the alleged insider trader is not generally available. ${ }^{27}$

Information is considered to be "generally available" if:

(a) it consists of readily observable matter; or

(b) ...(i) it has been made known in a manner that would, or would be likely to, bring it to the attention of persons who commonly invest in [securities] of a kind whose price might be affected by the information; and

\footnotetext{
${ }^{26}$ Rivkin's case, para 139.

${ }^{27}$ Corporations Act, 2001, s 1042A (Cth), previously s 1002G (1).
} 
(ii) since it was made known, a reasonable period for it to be disseminated among such persons has elapsed; or

(c) it consists of deductions, conclusions or inferences made or drawn from either or both of the following:

(i) information referred to in paragraph (a);

(ii) information made known as mentioned in subparagraph (b)(i). ${ }^{28}$

"Readily observable matter" is considered to mean "facts directly observable in the public arena.” ${ }^{29}$ It does not matter how many people actually observe the information (or, indeed, if any do) so long as it would be possible for them to observe it. ${ }^{30}$ Observation can occur by various means - for example, with the use of the "unaided human senses" and with the assistance of devices such as the "telephone, telex, facsimile, television and the internet." 31 Over recent years, there has been considerable confusion as to whether or not information needs to be readily observable in Australia or if it is sufficient if it is readily observable in an overseas jurisdiction. In $R v$. Firns ${ }^{32}$ ('Firns' case') the trial judge found that information which was readily observable overseas but not in Australia was not "generally available", and the defendant was convicted of insider trading. ${ }^{33}$ However, in $R v$. $\operatorname{Kruse}^{34}$ ('Kruse's case'), a case based on an almost identical situation, the trial judge found that, in order to be considered to be "generally available", it is sufficient if information is readily observable overseas, and the defendant was not convicted of insider trading. These two decisions appear irreconcilable, ${ }^{35}$ but the conviction in Firns' case was overturned on appeal by the New South Wales Court of Appeal and the majority of the Court found that information need only be readily observable in an overseas jurisdiction for it to be "generally available", although Carruthers AJ delivered a strong dissenting judgment. The majority judgment in the appeal in Firns' case now appears to represent the current state of the law, but the question as to who must be able to observe the relevant information, and where they must be able to observe it, has remained a contentious issue. ${ }^{36}$

\section{Determining when information is generally available}

At trial, counsel for Mr Rivkin unsuccessfully tried to argue that the information which Mr Rivkin possessed was generally available, due to the existence of ru-

\footnotetext{
${ }^{28}$ Corporations Act, 2001, s 1042C (Cth), previously s 1002B (2) and (3).

${ }^{29}$ Explanatory Memorandum, Corporations Legislation Amendment Bill, 1991, para 328 (Cth).

${ }^{30} \mathrm{R}$ v. Firns, (2001) 19 ACLC 1495 (NSWCCA, 2001).

${ }^{31}$ R v. Firns, (2001) 19 ACLC 1495, 1507 per Mason J (NSWCCA, 2001).

${ }^{32}$ R v. Firns, [1999] District Court of New South Wales, 98/11/0895 (Unreported, Sides J, Nov. 4, 1999) (District Court NSW).

${ }^{33}$ In that case the information in question was a judgment delivered by the Supreme Court of Papua New Guinea.

${ }^{34}$ R v. Kruse, [1999] 98/11/0908, (Unreported, O’Reilly J, Dec. 2, 1999) (District Court, NSW 1999).

${ }^{35}$ But contrast Gordon Walker, Insider Trading in Australia: When is information generally available?, 18 COMPANY S.L.J. 213, 215-216 (2000).

${ }^{36}$ See for example, Simon Rubenstein, The Regulation and Prosecution of Insider Trading in Australia: Towards Civil Penalty Sanctions for Insider Trading, 20 COMPANY S.L.J. 89, 103 (2002).
} 
mours in the press about the possibility of deals being done between two of the then four airlines operating domestically, as well as rumours about the possible collapse of Impulse Airlines. Whilst such rumours existed, the Crown was able to demonstrate an absence of information in the media about the proposed "merger" as described by Mr McGowan to Mr Rivkin. The Crown called expert evidence from several witnesses in the stockbroking industry, who testified that they were unaware of any rumours of such a proposal prior to the joint announcement by Impulse Airlines and Qantas on 1 May 2001.

As the Crown's evidence on this point was accepted, it was unnecessary for the trial judge or the New South Wales Court of Criminal Appeal to consider whether the existence of rumours about the proposed "merger" would have meant that the information was "generally available". This is an interesting issue because the status of rumours as a source of information has not previously been the subject of judicial pronouncement in Australia and guidance from the Court on this topic would have been of great assistance.

It is also regrettable that the Court did not take an opportunity to clarify the circumstances in which information will be considered to be "generally available". As discussed above, this question has been contentious in recent times, due to the inconsistency in approaches taken in Firns' case and Kruse's case. Questions relating to the "general availability" of information did arise in Rivkin's case, so although a detailed exposition of the meaning of the terms "readily observable" and "generally available" was not necessary in order for a decision to be made on the facts, it would still have been relevant and much-welcomed.

In an attempt to remove some of the confusion surrounding these concepts, the Corporations and Markets Advisory Committee ${ }^{37}$ ('CAMAC') has recently proposed that the test of whether information is "generally available" be reformulated: by deleting the first limb of the definition - which provides that information is generally available if it consists of "readily observable matter" - and by removing the requirement in the second limb - that a reasonable amount of time must have elapsed after information has been made known to people who commonly invest in that type of security. Under CAMAC's proposal, information would only be "generally available” if:

(a) it is accessible to persons who commonly invest in [securities] of a kind whose price might be affected by the information; or

(b) it consists of deductions, conclusions or inferences made or drawn from information referred to in paragraph (a). ${ }^{38}$

This proposal has not been accepted or adopted by Parliament and does not represent the current state of Australian law. However, this proposal would certainly remove the current confusion relating to the term "readily observable", as that term

\footnotetext{
${ }^{37}$ Formerly the Companies and Securities Advisory Committee.
}

${ }^{38}$ CAMAC, supra note 15 , at para 4.7.4. 
would no longer form part of the definition. However, a similar debate could erupt over the meaning of the term "accessible to". Whilst the proposal does provide that the information must be accessible to "persons who commonly invest" in the relevant securities, there may be doubt as to whether events occurring overseas or information being released overseas are "accessible" to such persons. Accordingly, the implementation of such a proposal may lead simply to the substitution of one contentious issue with another.

\section{A reasonable person would expect the information to have a material effect on the price or value of securities}

The third element of the insider trading offence requires that, if the relevant information was generally available, a reasonable person would expect it to have a material effect on the price or value of securities. ${ }^{39}$ A reasonable person is taken to expect information to have a "material effect" on the price or value of securities if, and only if, the information would, or would be likely to, influence persons who commonly acquire securities in deciding whether or not to acquire or dispose of the relevant securities. ${ }^{40}$

It appears to be commonly accepted that the Crown can seek to prove "materiality" by calling expert evidence from financial specialists as to whether they would consider such information to be likely to raise or lower the relevant share price once it becomes publicly known. Such evidence was led by the Crown in Rivkin's case and rebuttal evidence from similar experts was also led by the defence. Additionally, evidence can also be led of actual movements in share prices once the relevant information becomes generally available. ${ }^{41}$

\section{Is the source of information relevant when considering materiality?}

In Rivkin's case, counsel for Mr Rivkin argued that a reasonable person could not have considered the relevant information to be "material" because its content was uncertain and indefinite, and a potential investor would have regarded the information as being unreliable. The Court rejected this argument, although it did recognize that the source of information may have an impact on its materiality. ${ }^{42}$ That is, the more reliable the source is considered to be, the more likely it is that the information itself may be considered to be reliable and therefore likely to have a material effect on the price or value of securities.

\footnotetext{
${ }^{39}$ Corporations Act, 2001, s 1042A and s 1043A (Cth), previously s 1002G (1).

${ }^{40}$ Corporations Act, 2001, s 1042D (Cth), previously s 1002C.

${ }^{41}$ Gething, supra note 5, 619-620.

${ }^{42}$ Rivkin's case, para 134 and 137.
} 
As noted by Spigelman CJ in $R v$. Hannes ${ }^{43}$ and cited by the Court in Rivkin's case, ${ }^{44}$ "the effect on the price of securities of a mere prospect ...[is] less than the actuality..., but that does not mean that... [it] was irrelevant to an assessment of the materiality of the prospect." Clearly, a certain event is more likely to affect share prices than an uncertain event, but the possibility of an uncertain event occurring may still affect share prices as well.

In Rivkin's case, the Court considered that the fact Mr McGowan, the executive chairperson of Impulse Airlines, gave information about a proposal between Impulse Airlines and Qantas might make the information more likely to be reliable than if the same information had been received from an unrelated source. ${ }^{45}$ Accordingly, the source of the information could affect the materiality of the information because investors might consider some sources to be more credible or reliable than others.

The impact of this issue can again be demonstrated by considering the different types of information which may potentially circulate in the financial marketplace. There would obviously be a significant difference in the perceived reliability of the three examples of pieces of information set out at paragraph A1 above. Whether or not a person believes certain information to be true, or to be likely to be true, will obviously impact on the person's likeliness to rely on that information. Clearly, the information in example (i) above, being a press release issued by the relevant company, is much more likely to be considered to be reliable than the information in example (iii), being vague information overheard from a passer-by. The higher level of reliability is therefore also likely to impact on materiality, because there is a greater likelihood of the information affecting and influencing trading decisions.

Therefore, the source of information not only forms part of the information itself, but should also be considered when attempting to analyse whether or not information is material. The Corporations Act sets out the test for determining materiality whether or not information is likely to influence trading decisions by those who commonly trade in such securities - and the source of the information can be used to assist in making such an assessment.

\section{Knowledge that the information is not generally available and that a reasonable person would expect the information to be material}

The fourth and fifth elements of the insider trading offence are best considered together, as they both concern the knowledge of the alleged insider trader.

\footnotetext{
${ }^{43}$ R v. Hannes, (2000) 158 FLR 359 (NSWCCA, 2000).

${ }^{44}$ Rivkin's case, para 194.

${ }^{45}$ Rivkin's case, para 134.
} 
The fourth element requires that the alleged insider trader knows, or ought reasonably to know, that the relevant information is not generally available. ${ }^{46}$ The fifth element requires that the alleged insider trader knows, or ought reasonably to know, that if the relevant information were generally available, a reasonable person would expect it to have a material effect on the price or value of securities. ${ }^{47}$

It is not enough merely to demonstrate that the alleged insider trader possessed the relevant information. It must also be proved that the alleged insider trader knew that the information was not "generally available" and that the information was likely to be material, or that they should have had such knowledge.

It has long been recognised that these two "knowledge" elements of the insider trading offence are the most difficult to prove, and that this difficulty appears to create one of the greatest obstacles to the successful prosecution of insider trading offences. ${ }^{48}$

\section{$1 \quad$ How subjective are the tests for determining the level of knowledge that an alleged insider ought to have had?}

The question of what an alleged insider trader actually knew is obviously subjective, but is the question of whether an alleged insider trader "ought reasonably to have known" something an objective or subjective consideration?

A careful examination of the "knowledge" elements of the insider trading offence reveals that it must be proved that either:

(a) the alleged insider trader knew:

(i) that the relevant information was not generally available; and

(ii) that a reasonable person would have expected the information to be material; or

(b) that alleged insider trader ought reasonably to have known:

(i) that the relevant information was not generally available; and

(ii) that a reasonable person would have expected the information to be material.

The items in paragraph (a) would clearly require a subjective test of the actual knowledge of the defendant. Paragraph (b), concerned with what the alleged in-

\footnotetext{
${ }^{46}$ Corporations Act, 2001, s 1042A and s 1043A (1) (b) (Cth), previously s 1002G (1).

${ }^{47}$ Corporations Act 2001, s 1042A and s 1043A (1) (b) (Cth), previously s 1002G (1).

${ }^{48}$ As has been noted by the former Chair of the Australian Securities and Investments Commission, Alan Cameron, "proving that a person had knowledge is often harder than it sounds unless there is smokinggun type of evidence": Alan Deans, The Fetter of the Law, THE BulleTIN (Sydney), Nov. 28, 2000, as cited by Rubenstein, supra note 36, 106. Proof of the defendant's state of mind is recognised as one of the major difficulties faced in prosecuting a breach of the insider trading provisions: the Explanatory Memorandum, Financial Services Bill, 2001 para 2.78 to 2.79 (Cth); CAMAC, supra note 2, para 2.139; ROMAN TOMASIC, CASINO CAPITALISM? INSIDER TRADING IN AUSTRALIA, 115 to 126 (1991), available at <http://www.aic.gov.au/publications/lcj/casino/> (last visited June 1, 2005).
} 
sider trader "ought reasonably to have known” initially appears to require an objective test. Together, the two paragraphs seem to import both objective and subjective criteria.

However, it was stated by the Court in Rivkin's case that when considering what an alleged insider trader "ought reasonably to have known”, the question is subjective to the particular defendant, having regard to all of the relevant circumstances, including the appellant's mental state at the time. ${ }^{49}$ This means that one does not consider whether the theoretical reasonable person ought to have had certain knowledge, but whether the particular defendant in question ought to have had such knowledge, bearing in mind subjective factors such as their particular level of knowledge, experience, level of business and commercial expertise and any other relevant personal characteristics. In Rivkin's case, counsel for Mr Rivkin argued that, due to mental illness, it should not be considered that Mr Rivkin ought reasonably to have had such knowledge, but that argument was not ultimately successful.

Adopting subjective tests for determining what the alleged insider trader knew and ought to have known, leads to a rather clumsy result in respect of the second "knowledge" element, concerning the alleged insider trader's knowledge about the information's materiality. It means that it must be proved either that the alleged insider trader knew what a reasonable person would have expected, or ought to have known what a reasonable person would have expected, in relation to the materiality of the information.

Analysing the effect of the Court's pronouncement on this element of the insider trading offence, it seems that one must really consider:

(a) Did the defendant know that a reasonable person would have expected the information to have a material effect?

(b) If not (or if it cannot be proved), should the defendant have known that a reasonable person would have had that expectation?

Therefore, there appears to be a curious mix of objective and subjective tests within the knowledge elements of the insider trading offence. It is first considered objectively whether a reasonable person would have thought the information to be material. If so, it is then considered subjectively whether the alleged insider trader knew that the theoretical reasonable person would be considered to have had that expectation. If not, it is then considered subjectively whether the alleged insider trader ought to have known that the theoretical reasonable person would be considered to have had that expectation. Although the words used in the section - "reas-

\footnotetext{
${ }^{49}$ The New South Wales Court of Criminal Appeal cited the case of Boughey v. Queen, (1986) 161 CLR 10, 28-29 (High Court of Australia, 1986) as authority for that proposition and noted that it was accepted by both counsel for Mr Rivkin and the Crown: Rivkin's case, para 94.
} 
onably ought to have known" - may appear at first blush to involve an objective test, the Court has made it clear that the relevant test is subjective.

As a person can never actually know what a theoretical "reasonable person" would expect to know or do in any given circumstance, this test appears to be quite difficult to apply. If the defendant's relevant circumstances must be taken into account when considering these issues, the question essentially being asked is whether the particular defendant knew or should have known what others later presume that a hypothetical person might have been expected to know. In a practical sense, it would provide the same ultimate result to re-formulate the question in a more simple way: if it has been established that, if the relevant information were generally available, a reasonable person would expect it to have a material effect on the price or value of the relevant securities, is there any reason why the defendant would not also have had that expectation? The defendant's relevant circumstances could then be subjectively considered, in order to determine whether the defendant should have had any expectation different from that which has been objectively determined. The defendant's financial acumen, experience, education and other such factors would all be relevant to that assessment.

Whilst the pronouncement on this issue by the Court in Rivkin's case should be of assistance, by making it clearer what must be proved by the prosecution in order to establish the requisite knowledge of the defendant, the test is likely to prove difficult to apply or satisfy. This is unlikely to assist in any meaningful way in addressing the perceived difficulties in proving the knowledge elements of the insider trading offence.

Interestingly, the case of Boughey v. Queen, ${ }^{50}$ which was referred to by the Court in Rivkin's case when considering this issue, certainly imposed a subjective test in respect of the phrase “ought to have known” when determining, in a murder trial, whether a defendant "ought to have known" that certain actions were "likely to cause death". ${ }^{51}$ However, the phrase "ought reasonably to have known" which is used in respect of the insider trading offence, has been considered to impose an objective not a subjective test, when its use in other legislation has been considered. $^{52}$ Thus it is questionable whether a subjective test should be preferred over an objective test in relation to the insider trading offence.

If objective criteria were applied, the test could be reformulated as follows:

\footnotetext{
${ }^{50}$ Boughey v. Queen, (1986) 161 CLR 10, 28-29 (High Court of Australia, 1986).

${ }^{51}$ The defendant in that case had been tried and found guilty of murder under the Criminal Code Act, 1924, s 157 (1) (b) and (c) (Tas).

${ }^{52}$ See for example, Raben Footwear Pty Limited v. Polygram Records Inc, [1997] 370/97, (Unreported, Burchett, Tamberlaine and Lehane JJ, May 16, 1997), (FCA, 1997) in respect of the Copyright Act, 1968, ss 102 and 103 (Cth); Australian Securities and Investments Commission v. McLeod, [2000] SJA 1190/1998 (Unreported, Ipp, Anderson and Owen JJ) (Supreme Court of Western Australia 2000) in respect of the Corporations Law, s999.
} 
(a) Did the defendant know that a reasonable person would expect the information to have a material effect?

(b) If not (or if it cannot be proved), should a reasonable person in the defendant's position have known that a reasonable person would have that expectation?

Formulated in this way, the defendant's subjective circumstances would still be relevant, ensuring, for example, that those who are uneducated or inexperienced are not presumed to have the level of market knowledge of a stockbroker. However, the objective criteria would be easier to apply and would simplify the relevant tests.

Suggestions have been made that the complex issues concerning proof of knowledge of the defendant could be alleviated to a degree by reversing the onus of proof for one or both of the two knowledge elements of the insider trading offence. That is, once it has been proved that information was not generally available and that a reasonable person would consider the information to be material, there should be a rebuttable presumption that an alleged insider trader had that knowledge, unless the alleged insider trader is able to prove otherwise. ${ }^{53}$ The basis for such a proposal is that it would assist in the prosecution of alleged insider traders due to the fact, as noted above, ${ }^{54}$ that it is considered to be notoriously difficult to prove the two knowledge elements of the insider trading offence. Also, it is considered an alleged insider trader may be better placed to lead evidence about what they did or did not know than the prosecution. Whilst this proposition has certain merit and appeal, to date it has been rejected, primarily on the basis that the partial reversal of the onus of proof, and therefore the presumption of innocence, is not appropriate in the circumstances. $^{55}$

The Financial Services Reform Act ${ }^{56}$ recently implemented certain reforms to the insider trading provisions of the Corporations Act, one of which was to provide for an alternative civil penalty regime for insider trading. ${ }^{57}$ This regime has a lower standard of proof, based on the balance of probabilities. As the events which were the subject of Mr Rivkin's trial took place prior to the implementation of these reforms, the option of proceeding against Mr Rivkin under the civil penalty regime was not available. Whilst the use of such a regime may make it easier to successfully prosecute alleged insider traders in the future, it will not resolve the problem-

\footnotetext{
${ }^{53}$ See for example, Tomasic \& Pentony, supra note 4; a similar proposal was considered by the "Griffiths Committee” but was rejected: ALAN GRIFFITHS, FAIR SHARES FOR ALL: INSIDER TRADING IN Australia - AN OUtline OF THE Issues AND Alternatives, Report of the House OF REPRESENTATIVES JOINT STANDING COMMITTEE ON LEgAL AND CONSTITUTIONAL AFFAIRS, Australian Government Publishing SERViCes 4.10.1 (1990) (commonly referred to as the "Griffiths Report”).

54 See paragraph 4D above.

${ }^{55}$ This was the position adopted in the Griffiths Report, supra note 53, para 4.10.2; CAMAC, supra note 15, para 3.4 .

${ }^{56}$ Financial Services Reform Act, 2001, (Cth).

${ }^{57}$ Corporations Act, 2001, s 1317E (1) (Cth), as amended by the Financial Services Reform Act, 2001, Schedule 1, item 437 (Cth)
} 
atic issues surrounding the "knowledge" elements of the insider trading offence. Even if the standard of proof is lower, some evidence must still be led, so the difficulty faced by prosecutors is not entirely removed. The availability of criminal prosecution of insider trading and the resulting criminal sanctions must still be maintained in order to act as a deterrent and to retain consumer and market confidence in securities trading.

\section{Whilst in possession of the information, the person trades or procures trading in securities}

The final element of the insider trading offence requires that the alleged insider trader, whilst in possession of information as described above, either trades in the relevant securities ${ }^{58}$ or procures another person to trade in the relevant securities. ${ }^{59}$

This is one of the least contentious elements of the insider trading offence and generally it will not be in doubt, if the other elements have been satisfied, whether or not a person has traded or procured another to trade in securities. However, in $R$ $v$. Evans and Doyle, ${ }^{60}$ charges of insider trading were dismissed as a result of this issue. The defendants in that case had placed instructions with a broker to purchase securities prior to certain inside information becoming generally available. The trade was not actually effected by the broker until later that day, after a public release of relevant information. The defendants were prosecuted for insider trading on the basis that they had "entered into an agreement to purchase securities" whilst in possession of inside information. However, McDonald J determined that an agreement to purchase securities was not actually entered into until the broker had effected the trade, by which time the information had become generally available, so no offence was committed. The Corporations Act has now been amended so that a similar result would not necessarily occur in the future, with the relevant conduct including applying for, acquiring and disposing of securities, or entering into an agreement to do so. ${ }^{61}$

This element was not in issue in Rivkin's case, as it was clear that having given instructions for 50,000 Qantas shares to be purchased in the name of Rivkin Investments (of which Mr Rivkin was the sole director, with a shareholding interest of $11 \%)$ Mr Rivkin had procured another person to trade in Qantas shares, the relevant securities. The shares were purchased well before the relevant information was publicly released. The fact that Mr Rivkin had made a relatively small profit on the transaction, and could potentially have made more if the Qantas shares had been

\footnotetext{
${ }^{58}$ That is, applies for, acquires, disposes of or enters into an agreement to apply for, acquire or dispose of the relevant securities: Corporations Act, 2001, s 1043A (1) (c) (Cth). Previously, the relevant conduct was subscribing for, purchasing, selling or entering into an agreement to subscribe for, purchase or sell the relevant securities: s $100 \mathrm{G}$ (2).

${ }^{59}$ Corporations Act, 2001, s 1043A (1) (d) (Cth), previously s 1002G (2).

${ }^{60}$ R v. Evans and Doyle, [1999] BC9908092 (Unreported, McDonald J, Nov. 15, 1999), (Supreme Court of Victoria, 1999).

${ }^{61}$ Corporations Act, 2001, s 1043 A (1) (Cth).
} 
sold after, rather than before, the joint announcement by Qantas and Impulse Airlines, was not a relevant factor in determining whether an offence had been committed, or in determining the seriousness of the offence. Indeed, as noted by the trial judge, whose comments were affirmed by the New South Wales Court of Criminal Appeal in its judgment, ${ }^{62}$ "[i]t cannot be regarded as a trivial offence... because of the modest size of the profit.” ${ }^{3}$

Interestingly, no offence is committed if a person who had been intending to trade in securities, comes into possession of some "inside information" and then decides not to trade. Additionally, that person may also pass that information onto others for the purpose of convincing them not to trade, but not to procure them to trade in securities. CAMAC considered this issue in its recent review of insider trading laws and recommends that this aspect of the law on insider trading remain unchanged. ${ }^{64}$ The rationale for permitting a person to make a decision not to trade in securities, which is based on "inside information", but prohibiting them from making a decision to trade in securities based on the same information, relies on the view that as there is no other party to the trade, there is no party who is actually disadvantaged by that action or in-action. Obviously, it would also be almost impossible to prove that a decision not to trade had been made in those circumstances.

\section{IMPORTANCE OF THE COURT'S PRONOUNCEMENTS IN RIVKIN'S CASE}

As noted above, ${ }^{65}$ insider trading regulation has long been viewed as an extremely difficult and complicated area, and the judgment in Rivkin's case is likely to be of some assistance in resolving complex questions about some of the contentious elements of the insider trading offence. However, consideration must be given to the fact that it is hardly desirable that an offence which has been the subject of relatively recent legislative reform, is still in need of extensive judicial interpretation to resolve unnecessary uncertainty. For example, the question as to whether the information must be "readily observable" in Australia in order to be considered to be "generally available", could easily be addressed and resolved by an amendment to the Corporations Act. It should not be necessary to rely on the courts to resolve the uncertainties created when the legislature is unable to clearly express the required elements of the insider trading offence. Unfortunately, due to the question marks which still remain over issues such as this, cases such as Rivkin's case will continue to be looked upon as to key to reform and resolution. As noted by Rolfe $\mathrm{J}$ in relation to the insider trading laws:

\footnotetext{
${ }^{62}$ Rivkin's case, para 392.

${ }^{63}$ R v. Rivkin, [2003] 447 (Unreported, 70065/02, Whealy J, May 29, 2003), para 49 (NSW Supreme Court, 2003).

${ }^{64}$ CAMAC, supra note 15 , para 3.4 .

${ }^{65}$ See paragraph 1 above.
} 
It is a matter of concern that legislative provisions, which create serious criminal offences... should provide... difficulties of interpretation.... I would respectfully suggest that reconsideration be given to these provisions. ${ }^{66}$

His Honour's frustrations must surely be shared by corporate lawyers and academics alike.

\section{An International Perspective}

As has already been briefly mentioned above, Australian law on insider trading differs in certain significant respects from the majority of overseas jurisdictions with well-developed insider trading laws. It is interesting to consider the effect of these differences on the circumstances which gave rise to the prosecution and conviction of Mr Rivkin for insider trading.

The major points of distinction in relation to Australian insider trading law are:

(a) in Australia, there is no requirement to demonstrate that the alleged insider trader "used" the inside information (or a defence of "non-use" of inside information);

(b) in Australia, information no longer needs to be "specific"; and

(c) in Australia, there is no longer any distinction between "primary" and "secondary" insiders.

The issue of the "use" of inside information has been discussed above. ${ }^{67}$ The trial judge in Rivkin's case was satisfied that Rivkin did rely on the inside information received from Mr McGowan when making a decision to trade in Qantas shares. ${ }^{68}$ Accordingly, the existence of a requirement to prove "use" of information or the availability of a defence of "non-use" would have been unlikely to have lead to a different result in Mr Rivkin's trial.

The issue of "specificity" of information has also been discussed above. ${ }^{69}$ Whilst it appears that there was not actually a proposal to actually "merge” Impulse Airlines and Qantas, as was described by Mr McGowan to Mr Rivkin, this is essentially a question of inappropriate terminology. If a test of specificity of information had been required it would most likely have been satisfied, due to the otherwise detailed

\footnotetext{
${ }^{66}$ Ampolex Ltd v. Perpetual Trustee Trading Co (Canberra) Ltd, (1996) 20 ACSR 649, 658 (NSW Supreme Court, 1996) as cited in HAROLD FORD, ROBERT AUSTIN \& IAN RAMSAY, FORD'S PRINCIPLES OF CORPORATIONS LAW 9.640 (12 ${ }^{\text {th }}$ ed., 2005).

${ }^{67}$ See paragraph IV above.

${ }^{68}$ R v. Rivkin, [2003] New South Wales Supreme Court, 447 (Unreported, 70065/02, Whealy J, May 29, 2003), para 24 (NSW Supreme Court, 2003).

${ }^{69}$ See paragraph IV above.
} 
nature of the information provided by Mr McGowan - the need for ACCC approval, a warning not to deal in Qantas shares and disclosure of the obvious existence of a major confidential transaction about to occur between Qantas and Impulse Airlines. Thus a requirement that information be "specific" would have been unlikely to have lead to a different result.

Most overseas jurisdictions make a distinction between the position of "primary" insiders and "secondary" insiders. ${ }^{70}$ The relevant tests vary between jurisdictions but, in general terms, primary insiders are those who possess inside information because of some connection with the relevant company (for example, directors, shareholders, employees and those who have a professional relationship with the company) and who have derived the inside information by virtue of that connection. Secondary insiders are those who possess inside information but have no particular connection to the relevant company. Most jurisdictions require that a secondary insider knowingly receive the relevant information directly or indirectly from a primary insider. Prior to 1991, a distinction between primary and secondary insiders existed in Australia, ${ }^{71}$ but this was abolished in the reforms which followed the Griffiths Report. ${ }^{72}$

Generally, both primary insiders and secondary insiders are prohibited from trading or procuring trading in the relevant securities. If a distinction had existed between primary and secondary insiders at the time Mr Rivkin bought and sold the relevant Qantas shares, Mr Rivkin would most likely have been considered to be a secondary insider. As was submitted by counsel for Mr Rivkin, he was "not... a 'true insider' [because he was not] an officer of... Impulse or Qantas, or... involved in the deal, or... in a position of trust in relation to the information.”73 However, $\mathrm{Mr}$ Rivkin acquired the information directly from Mr McGowan, the executive chairperson of Impulse Airlines. Mr McGowan would most likely be regarded as a primary insider, due to his role in negotiating the deal between Impulse Airlines and Qantas. Accordingly, Mr Rivkin would have received the inside information directly from a primary insider, in circumstances where Mr Rivkin was well aware of the nature of the information. Accordingly, a distinction between primary and secondary insiders would have been unlikely to have led to a different result in this case.

Overall, it is interesting to note that even though Australian maintains three significant points of distinction compared with the majority of jurisdictions with well-

\footnotetext{
${ }^{70}$ See for example, Canada (Securities Act, 1990, s 76 (5) (a) to (d), s 76 (5) (e) (Ontario)); the European Union (Directive 2003/6/EC, Insider Dealing and Market Manipulation (Market Abuse), Article 2 and Article 4); Germany (Securities Trading Act, 1994, s 13 (1) and s 14 (2) (Germany)); New Zealand (Securities Amendment Act, 1988, s 3 (1) (NZ)); Singapore (Securities Industry Act, 1986, s 203 (c) to (f) (MAS); South Africa (Insider Trading Act, 1998, s 1 (viii) (a) and s 1 (viii) (b) (South Africa)); the United Kingdom (Criminal Justice Act, 1993, s 57 (2) (a), s 57 (1) and (2) (b) (UK)); the United States (Dirks v. SEC, 463 US 646 at 655 (1983); Shaw v. Digital Equipment Corp, 82 F.3d 1194 (1996); United States v. O’Hagan, 117 S Ct 2199; and SEC v. Falbo, 14 F.Supp 2d (1998)).

${ }^{71}$ Securities Industry Code, 1980, s 128 (Cth).

${ }^{72}$ GRIFFITHS, supra note 53.

${ }^{73}$ Rivkin's case, para 409.
} 
developed insider trading laws, if those distinctions were to be disregarded $\mathrm{Mr}$ Rivkin would most likely still have been convicted of insider trading.

\section{CONCLUSIONS}

Overall, the judgment of the New South Wales Court of Criminal Appeal in Rivkin's case should be viewed as a much-needed and welcome pronouncement on the state of the law concerning insider trading. With so few decided cases in this area of the law, particularly successful convictions and prosecutions following a plea of not guilty, Rivkin's case has provided a rare opportunity for judicial review and consideration of the insider trading offence, which has long been considered an extremely difficult offence to prosecute.

As a result of the Court's decision in Rivkin's case and the reasons provided for that decision, the following aspects of the law of insider trading are now much less in doubt, as it is has become clearer that:

(a) the nature of information which is caught by the definition in the insider trading offence can include the source of the information, as well as the actual state of affairs communicated;

(b) there is no requirement that the relevant information be received under an obligation of confidence; and

(c) the source of information received can be relevant when determining the extent of its potential reliability and therefore its materiality.

However, the uncertainty which has existed as to the meaning and scope of the terms "readily observable" and "generally available" has not been resolved. For certainty, this issue requires future clarification in some form. Also, whilst it is helpful that it is now clear that the test for determining what an alleged insider trader "ought reasonably to have known" is primarily subjective in nature, the application of such a test is likely to be convoluted and clumsy. It is highly desirable that this issue be simplified in the future.

Despite these criticisms, the New South Wales Court of Criminal Appeal's pronouncements in Rivkin's case should greatly assist in the understanding and analysis of insider trading laws. The additional clarity that has been provided by the judgment in Rivkin's case will hopefully assist in ensuring that the elements of the offence are better understood. Whilst it cannot be said that all uncertainty relating to the insider trading offence has been resolved, the clarification which has been provided by Rivkin's case may alleviate some of the perceived difficulties in successfully mounting prosecutions of insider trading in Australia. 